\title{
PENGARUH FREQUENT FLYER RELATIONSHIP PROGRAM TERHADAP LOYALITAS PENUMPANG GARUDA INDONESIA (Survei pada member Garuda Frequent Flyer )
}

\author{
Kinanti Pra Ramdhani \\ Vanessa Gaffar \\ Manajemen Pemasaran Pariwisata FPIPS UPI
}

\begin{abstract}
The tourism industry is the single largest source of foreign exchange that allows for more developed in the future. Tourism enterprises are businesses that provide goods and / or services to meet the needs of tourists and tourism. One is the air transport industry or airlines that meet the needs of tourists. Garuda Indonesia Airlines is one of the commercial airline owned by the government of Indonesia stir in the field of air transport which now serves more than 50 domestic routes and international destinations. Garuda Indonesia Airlines passenger numbers have fluctuated each year experience. Garuda Indonesia Airlines seek to maintain and improve the passenger to use the return of Garuda Indonesia Airlines, as well as the members who have been repeatedly used to be a spiritual eagle so that advocates can recomment it to others. That the higher the level of competition in the industry Airlines, makes the management realized that needs a strategy to reach the target customer loyalty. To improve passenger loyalty, one of the programs conducted by Garuda Indonesia Airlines is the Frequent Flyer Relationship Programs at Garuda Indonesia to enhance member loyalty. The purpose of this study was to obtain an overview of frequent flyer program relationship, loyalty and the effect relationship freqeunt flyer loyalty program. This type of study is a descriptive verifikatif and methods used are probability sampling with random sampling technique sistematic and the number of respondents that as many as 100 respondents Garuda frequent flyer member. Data analysis technique used is a tool path analysis with SPSS 18.0 computer software, interviews and distributing questionnaires as data collection techniques. The study findings suggest that, frequent flyer program relationship with the dimensions used are benefits, interest, greeted personally, and prestige have high impact on member loyalty Garuda Indonesia Airlines. Dimensions of relationship-forming frequent flyer program that has the benefit of high influence. As for advice to companies is to maximize the Garuda Frequent flyer programs and services in order to improve and maintain member loyalty in Garuda Indonesia Airlines.
\end{abstract}

Keywords: freqeunt flyer program relationship, loyalty

\section{PENDAHULUAN}

1.1 Latar Belakang Penelitian

Pariwisata merupakan salah satu perjalanan yang dilakukan oleh seseorang atau lebih dengan tujuan di antara lain untuk mendapatkan kenikmatan dan memenuhi keinginan mengetahui sesuatu, kepentingan untuk melakukan kegiatan olah raga untuk kesehatan, konvensi, keagamaan dan keperluan usaha lainnya. Industri pariwisata merupakan salah satu sektor yang mengalami perkembangan di dunia, yang dapat mempengaruhi perekonomian penghasil devisa, oleh karena itu seiring berjalannya waktu industri pariwisata semakin berkembang, di era globalisasi sekarang persaingan bisnis semakin pesat walaupun sedang mengalami krisis global.

$$
\text { Menurut WTO, banyaknya }
$$

wisatawan dunia pada tahun 2000 telah mencapai 688 juta orang, diperkirakan jumlah wisatawan ke luar negeri akan bertambah di tahun 2010 menjadi 1 milyar dan di tahun 2020 menjadi 1,6 milyar orang. Suatu kenyataan bahwa pariwisata sudah menjadi kekuatan global yang dapat merubah dunia. Industri penerbangan beberapa tahun ini menunjukkan perkembangan, data dari departemen perhubungan bahwa penumpang pesawat tahun 2010 meningkat sebersar 22,39\% dibanding tahun sebelumnya. Tahun 2010 jumlah penumpang mencapai 43,77 juta orang. Peningkatan jumlah penerbangan domestik dari tahun 2003-2009 di bandara Soekarno-Hatta dapat di lihat pada Tabel 1.1 sebagai berikut: 
TABEL 1.1

DATA STATISTIK PENUMPANG GARUDA INDONESIA AIRLINES

\begin{tabular}{|c|c|c|c|c|}
\hline \multirow{2}{*}{ Tahun } & \multicolumn{2}{|c|}{ Penumpang Domestik } & \multicolumn{2}{c|}{$\begin{array}{c}\text { Penumpang } \\
\text { Internasional }\end{array}$} \\
\cline { 2 - 5 } & Jumlah & Persentage & Jumlah & Persentage \\
\hline $\mathbf{2 0 0 7}$ & $6,959,943$ & $6,9 \%$ & $2,268,620$ & $2 \%$ \\
\hline $\mathbf{2 0 0 8}$ & $7,591,810$ & $7,5 \%$ & $2,424,450$ & $2,4 \%$ \\
\hline $\mathbf{2 0 0 9}$ & $7,988,855$ & $7,9 \%$ & $2,324,174$ & $2,5 \%$ \\
\hline $\mathbf{2 0 1 0}$ & $8,734,644$ & $8,7 \%$ & $2,656,928$ & $2,6 \%$ \\
\hline $\mathbf{2 0 1 1}$ & 9.582 .236 & $9.3 \%$ & 3.158 .652 & $3.5 \%$ \\
\hline
\end{tabular}

Sumber: Garuda Indonesia 2012

Berdasarkan Tabel 1.1 dapat dilihat salah satu industri penerbangan yang mengalami perkembangan yang cukup baik yaitu maskapai penerbangan garuda indonesia. Salah satu faktor yang mempengaruhi industri pariwisata.

Hal ini mengakibatkan garuda indonesia memiliki perkembangan yang sangat baik oleh karena itu garuda indonesia dapat mempertahankan dan memelihara penumpang agar tetap loyal mengunkan garuda indonesia.

Garuda Indonesia untuk mengantisipasi perubahan yang terjadi dalam pesaing lingkungan bisnis jasa penerbangan agar tetap tercipta kepuasan pelanggan sepenuhnya dengan meluncurkan salah satu program layanan Garuda Frequent Flyer (GFF) Program GFF merupakan membership dan sebuah penghargaan kepada penumpang yang sering terbang menggunakan Garuda Indonesia, Program Garuda frequent flyer (GFF) memberikan kemudahan dalam melakukan penerbangan, adanya penghargaan terhadap penumpang yang berkali-kali terbang dengan Garuda Indonesia yaitu mendapatkan mileage yang sudah di kumpulkan. Keanggotan GFF juga memberikan berbagai pelayanan istimewa seperti counter chek-in khusus, fasilitas tambahan bagasi dan akses ke Garuda Indonesia Executive Lounge di bandara, GFF juga memberikan layanan dan produk yang di tawarkan oleh Mitra GFF, dengan demikian semakin sering penumpang menggunakan GFF semakin banyak kemudahaan dan pelayanan yang di terima membership GFF. Hal ini adalah sebagai salah satu program kerjasama yang akan memudahkan pengguna maskapai Garuda Indonesia

(sumber: gff.garuda-indonesia.com).

Program ini merupakan salah satu aspek untuk memelihara loyalitas penumpang, Garuda Indonsia memiliki membership salah satunya untuk menjalin hubungan yang baik dan memelihara loyalitas dengan penumpang. Berikut ini dapat dilihat data jumlah penumpang Garuda Frequent Flyer pada Tabel 1.2 sebagai berikut:

TABEL 1.2

JUMLAH PENUMPANG MEMBER GARUDA FREQUENT FLYER

\begin{tabular}{|c|c|c|}
\hline Tahun & $\begin{array}{c}\text { Total Garuda } \\
\text { Frequent Flyer }\end{array}$ & Persentage \\
\hline $\mathbf{2 0 0 8}$ & 656.372 & $31 \%$ \\
\hline $\mathbf{2 0 0 9}$ & 453.764 & $27 \%$ \\
\hline $\mathbf{2 0 1 0}$ & 464.348 & $21 \%$ \\
\hline $\mathbf{2 0 1 1}$ & 578.354 & $24 \%$ \\
\hline
\end{tabular}

Sumber: Garuda frequent flyer 2012

Pada Tabel 1.2 dapat dilihat jumlah pertumbuhan penumpang Garuda frequent flyer pada tahun 2008 jumlah penumpang $31 \%$ kemudian pada pengalami penurunan tahun 2009 sebesar $27 \%$ penumpang dan tahun 2010 sebesar $21 \%$ kemudian tahun 2011 mengalami kenaikan sebesar 3\%. Dilihat dari data diatas tidak mengalami fluktuatif dan tidak meningkat cukup tinggi. Bila dilihat pada jumlah pertumbuhan penumpang secara keseluruhan mengalami peningkatan pada tiap tahunnya akan tetapi belum mencapai target yang diharapkan manajemen GFF yaitu sebesar 30\% pada tahun ini. Dilihat dari data-data di atas jumlah penumpang Garuda frequent flyer mengalami fluktuatif dan belum mencapai target yang diharapkan. Hal ini menunjukan adanya gejala menurunnya loyalitas penumpang Garuda Indonesia.

Anggota garuda frequent flyer terdapat beberapa tingkatan dimulai dari junior, blue, silver, gold, platinum dan cobrand. Oleh sebab itu untuk memelihara loyalitas penumpang Garuda Indonesia memberikan program yang akan meningkatkan loyalitas penumpang. Hal ini sangat penting bagi Garuda Indonesia untuk mempertahankan dan meningkatkan loyalitas penumpang dengan terus meningkatkan pelayanan yang dimiliki dalam mempertahankan dan meningkatkan loyalitas pelanggan. Selain itu faktor yang mendukung dalam meningkatkan dan mempertahankan loyalitas pelanggan adalah relationship yang dijalin perusahan dengan pelanggannya, orientasi pelanggan dan kepercayaan yang berikan penumpang bagi Garuda Indonesia. Salah satu strategi pemasaran yang di 
lakukan Garuda Indoneasia dengan memberikan pelayanan yang optimal dalam meningkatkan loyalitas pelanggan.

Salah satu faktor yang paling berperan peting adalah kegiatan pemasaran. Salah satu kegiatan pemasaran yang dapat menjadi keuntungan adalah kegiatan kerjasama yaitu kegiatan pemasaran dimana dua atau lebih organisasi, melakukan kerjasama sebagai sinergi pemasaran. Kegiatan Relationship marketing yang dilakukan Garuda Indonesia bertujuan untuk memudahkan dan memberikan keuntungan bagi perusahaanperusahaan yang melakukan kerjasama tersebut. Program Relationship marketing yang dijalankan oleh Garuda Indonesia, kerjasama yang dijalin untuk memberikan kemudahan serta keuntungan bagi penumpang sehingga menibulkan loyalitas.

Menurut kotler dan keller (2009:60) Relationship Marketing adalah suatu hubungan pemasaran yang bertujuan untuk membangun hubungan saling memuaskan yang berjangka panjang dengan tujuan dalam untuk mendapatkan dan mempertahankan tujuan bisnis.

Berdasarkan uraian di atas yang terjadi dalam latar belakang tersebut berdasarkan fenomena yang ada, maka di lakukan penelitian tentang Frequent flyer relationship program dan loyalitas pelanggan.

Dengan demikian penelitian ilmiah ini berjudul "Pengaruh Frequent Flyer Relationship Program Terhadap Loyalitas Penumpang Di Garuda Indonesia" (Survei Pada member Garuda frequent flyer ).

\subsection{Rumusan Masalah}

Berdasarkan latar belakang di atas, maka dapat rumusan masalah penelitian sebagai berikut:

1. Bagaimana Frequent flyer relationship program di Garuda Indonesia.

2. Bagaimana loyalitas penumpang di Garuda Indonesia.

3. Seberapa besarkah pengaruh frequent flyer relationship program terhadap loyalitas penumpang di Garuda Indonesia.

\subsection{Tujuan Penelitian}

Berdasarkan rumusan masalah di atas, maka tujuan penelitian ini untuk memperoleh temuan mengenai :

1. Frequent flyer relationship program di Garuda Indonesia

2. Loyalitas di Garuda Indonesia
3. Frequent flyer relationship program terhadap loyalitas penumpang di Garuda Indonesia.

\subsection{Kegunaan penelitian}

a. Kegunaan teoritis

Secara teoritis hasil penelitian ini diharapkan dapat memberikan pengetahuan dalam memperluas wawasan mengenai ilmu pemasaran pariwisata, terutama tentang frequent flyer relationship program dan loyalitas pelanggan di industri penerbangan komersial dan sebagai referensi bagi pihak lain, untuk mengetahui dinamika dan fenomena perkembangan kepariwisataan dan wawasan penulisan mengenai manajemen pemasaran destinasi dan penelitian ini (Frequent flyer relationship program terdahap loyalitas penumpang di Garuda Indonesia).

\section{b. Kegunaan praktis}

Secara praktis hasil penelitian ini diharapkan dapat memberikan masukan kepada PT (persero) Garuda Indonesia dan para mitra kerjanya supaya lebih meningkatkan strategi pemasarannya demi kemajuan perusahaannya dengan dilakukan penelitian ini dapat menjadi pengetahuan dan motivasi bagi perkembangan industri penerbangan.

\section{KERANGKA PEMIKIRAN DAN HIPOTESIS}

\subsection{Kerangka Pemikiran}

Dapat diketahui bahwa pada Tahun 1950-an pemasaran berfokus pada barangbarang konsumen. Pada tahun 1960-an pemasaran ditunjukan pada pasar 507ecogniz. Selanjutnya pada Tahun 1970an pemasaran ditunjukan kepada pemasaran non profit atau pemasaran 507 ecogn. Sedangkan pada tahun 1990-an pemasaran terfokus pada Relationship Marketing dan pada Tahun 2000-an berfokus pada masa depan dari pemasaran itu sendiri.

Menurut Donaldson dalam Vanessa (2007:26) karakteristik yang membedakan antara berbagai jenis pertukaran adalah pertukaran yang didasari transaksi pasar dan pertukaran relasional, atau disebut juga dengan pendekatan transaksional dan relationship marketing. Pendekatan transaksional akan berfokus pada transaksi yang bersifat jangka pendek, mengutamakan pesaing, serta independen. Sedangkan pendekatan relationship berfokus pada pada kemitraan yang bersifat jangka panjang, 
mengutamakan kolaborasi dan kooperasi sehingga memberikan nilai pada kepada hubungan tersebut.

Menurut kotler dan keller (2009:60), "Relationship marketing aim to build mutually statisfying long-term relationships with key constitutes in order to earn and retain their business". Dengan kata lain relationship marketing atau hubungan pemasaran bertujuan untuk membangun hubungan saling memuaskan yang berjangka panjang dengan tujuan dalam rangka untuk mendapatkan dan mempertahankan bisnis mereka.

Berdasarkan pada berbagai definisi di atas, relationship marketing diartikan sebagai kegiatan pemasaran pada perusahaan yang ditunjukan kepada pendirian, pembangunan dan pemeliharaan pertukaran hubungan serta cara berfikir mengenai pelanggan dan penciptaan nilai untuk mempertahankan hubungan jangka panjang dengan maksud mempertahan bisnis perusahaan tersebut. Oleh sebab itu relationship marketing sangat dalam mempertahankan pelanggan karena mempertahankan pelanggan lebih sulit dibandingkan dengan memperoleh pelanggan baru.

Semakin berkembangnya waktu maka konsep relationship marketing mengalami perkembangan. Gummesson dalam Vanessa (2007:30) menyebutkan :

Perkembangan relationship marketing dan total relationship marketing (TRM). Konsep ini menyatakan bahwa relationship marketing merupakan pemasaran yang didasarkan atas interaksi antara berbagai jaringan. Gummesson membagi TRM ke dalam dua kategori besar yaitu market relationships dan non-market relationship. Marketing relationship merupakan hubungan anatara suppliers, pelanggan, pesaing, dan mereka yang beroperasi di pasar. Sedangkan non-market relationships secara langsung mempengaruhi koefisien market relationships.

Menurut Fandy Tjiptono (2009:215) konsep relationship marketing tidak hanya terbatas pada antara perusahaan dengan pelanggan saja namun mencakup jalinan relasi dengan berbagai pihak.

$$
\text { Menurut Ali Hasan (2010:127) }
$$

Customer relationship management merupakan konsep pemasaran yang fokusnya berdasarkan pada hubungan dengan pelanggan. Keberhasilan customer relationship management sebagai salah satu konsep pemasaran terletak dari seberapa jauh kemampuannya mempersatukan fungsi pemasaran dan fungsi penjualan untuk memaksimalkan fungsi-fungsi perusahaan.

Menurut Gharam Hoskins dan Sheth parvatiyar dalam Vanessa (2001:185) Suatu perantara dalam menciptakan loyalitas pelanggandalam rangka meningkatkan pendapatan dan menyampaikan manfaat bisnis dengan memfokuskan kepada penyampaian layanan pelanggan.

Frequent flyer relationship program salah satu program yang termasuk dalam kategori continuity program, dalam frequent flyer program terdapat empat dimensi yang disimpulkan menurut Mary M. Long, Sylvia D.Clark, Leon G. Schiffman and Charles Mchmellon dalam jurnal frequent Flyer Relationship Program and Business Travellers' Quality of life, mengemukakan :Relationship marketing as it applies to service it also described as serving customer as client' in order to enhance the relationship from customer's point ot view. Thus, the goal of any relationship strategy is make customer loyal and maintain an on going relationship. Dapat diartikan sebagai berikut hubungan pemasaran yang berlaku untuk layanan kepada pelanggan sebagai klien dalam meningkatkan hubungan dengan pelanggan dan salah satu strategi untuk membuat pelanggan loyal dalam kerjasama yang dijalin.

Dengan demikian, tujuan dari setiap strategi hubungan adalah membuat pelanggan setia dan memelihara hubungan yang sedang berjalan dari relationship strategy adalah untuk membuat para pelanggan loyal menjalin hubungan dalam jangka panjang.

Berikut ini keuntungan relationship strategy dari frequent Flyer Relationship Program and Business Travellers' Quality of life, yang mengemukakan sebagai berikut: frequent flyer relationship progam, because of the lager amount of flying they do, frequent of benefit from these programmes not only throught frequent flyer miles but also from access to private clubs at airports, frequent program may be recougnised and greeted personally by airline personnel who recognise them as frequent customer dapat diartikan sebagai berikut frequent flyer relationship program karena seringnya melakukan penerbangan maka adanya manfaat dari program ini, seperti klub khusus atau fasilitas tempat khusus di airports, pelayanan secara individu yang 
diterima secara pribadi oleh personil penerbangan yang mengenali mereka sebagai pelanggan sering. Program ini biasanya berbentuk kartu anggota yang juga merupakan kartu kesetiaan. Pelanggan yang memiliki kartu tersebut akan memperoleh penghargaan berupa poin, diskon dan dapat membeli produk lain yang disediakan oleh perusahaan.

Merurut uraian diatas dapat ditarik kesimpulan ada empat dimensi yaitu benefit from these program (keuntungan dari program frequent flyer), the interest of this program (daya tarik dari program GFF), prestige frequent flyer (reward atau penghargaan dari program GFF).

Menurut Mary M. Long, Sylvia D.Clark, Leon G. Schiffman and Charles Mchmellon dalam jurnal frequent Flyer Relationship Program and Business Travellers' Quality of life, maka terdapat empat dimensi frequent flyer relationship program yaitu sebagai berikut:

1. Benefit from these program, memberikan konsumen dengan memberikan segala keuntungan dan kemudahan untuk memenuhi keinginan konsumen. Melalui kerjasama dengan beberapa tehnik dan program (membership\& potongan harga).

2. The interest of this program, daya tarik dari program frequent flyer relationship.

3. Greedet personally (pelayangan secara individu), Pelayanan frequent flyer program yang di terima pelanggan dengan pelayanan secara individu yang diterima secara pribadi oleh personil penerbangan yang mengenali mereka sebagai pelanggan sering.

4. Prestige frequent flyer program (reward atau penghargaan dari program frequent flyer, memperlakukan pengguna program member dengan mendapatkan perlakuan khusus.

Memiliki tamu yang loyal adalah salah satu tujuan akhir dari sebuah perusahaan. Dengan demikian adanya loyalitas pada pelanggan, dapat menjamin keberhasilan dari sebuah perusahaan dalam jangka panjang. Selama ini loyalitas pelanggan sering kali dikaitkan dengan perilaku pembelian ulang. Dalam konteks merek, loyalitas mencerminkan komitmen psikologis terhadap merek tertentu, sedangkan perilaku pembelian ulang sematamata menyangkut pembelian merek tertentu yang sama secara berulang kali.

Menurut Jill Griffin (2005:4) Wujud perilaku dari unit-unit pengambilan keputusan untuk melakukan pembelian secara terus menerus terhadap barang atau jasa suatu perusahaan yang dipilih. Menurut Gremler dan Brown (dalam Ali asan, 2008:83) Loyalitas pelanggan adalah pelanggan yang tidak hanya membeli ulang suatu barang dan jasa, tetapi juga mempunyai komitmen dan sikap yang positif terhadap perusahaan jasa.

Menurut Griffin (2009:31) pelanggan yang loyal merupakan aset penting bagi perusahaan, hal ini dapat dilihat dari karakteristik yang dimilikinya. Pelanggan yang loyal memiliki karakteristik yaitu, melakukan pembelian secara terartur (makes regular repeat purchase), membeli diluar lini produk/jasa (purchases across product and service line), merekomendasikan kepada orang lain (refers other), serta menunjukan kekebalan dari daya tarik produk sejenis dari pesaing (demonstrase immunity to the full of the competition).

Untuk menjadi pelanggan yang loyal, seseorang harus melalui beberapa tahapan yang melalui suatu proses yang dapat berlangsung lama. Tamu yang loyal merupakan asset terpenting bagi sebuah perusahaan. Hal ini dapat dari karakteristik yang dimilikinya, seperti yang diungkapkan Griffin (2009:31) pelanggan yang loyal memiliki karakteristik yaitu:

1. Melakukan pembelian secara teratur (makes regular repeat purchases)

2. Membeli di luar lini produk atau jasa (purchase across product and service lines)

3. Merekomendasikan kepada orang lain (refers other)

4. Menunjukkan kekebalan daya tarik produk sejenis dari pesaing (demonstrates immunity to the full of the competition).

Loyalitas/kesetiaan, namun bagaimana suatu perusahaan dapat mempertahankan pelanggan tersebut dalam jangka panjang. Sehingga menurut Griffin pelanggan merupakan bagian penting dalam meraih loyalitas pelanggan yang diharapkan.

Customer relationship management strategi yang digunakan untuk memelihara hubungan pelanggan dalam jangka panjang, bertujuan untuk mempertahankan pelanggan dan sama menggunakan pembentukan hubungan guna memberikan keuntungan bagi kedua belah pihak.

Program continuity adalah bagian dari customer relationship management memiliki tiga jenis program yaitu continuity program, one to one marketing, dan partnering program, dimana frequent flyer relationship 
program adalah sebuah program relationship marketing yang biasanya dilakukan perusahan penerbangan atau airline yang bertujuan untuk mempertahankan pelanggan dan meningkatkan loyalitas melalui pelayanan khusus jangka panjang yang berpotensi untuk meningkatkan nilai melalui saling mempelajari masing-masing pihak.

Program ini berupaya untuk memberikan perhatian yang besar guna mempertahankan pelanggan, menyebabkan banyak perusahaan berusaha mengembangkan program pemasaran berkesinambungan untuk mempertahankan pelanggan dan meningkatkan loyalitas mereka Salah Satunya program yang dimiki Garuda Indonesia Airlines adalah layanan Garuda Frequent Flyer (GFF) Program GFF merupakan membership, Maka kegiatan frequent flyer relationship program memiliki peranan penting dalam mempengaruhi loyalitas penumbang Airlines Selanjutnya model kerangka penelitian ini digambarkan pada Tabel 2.2 sebagai berikut:

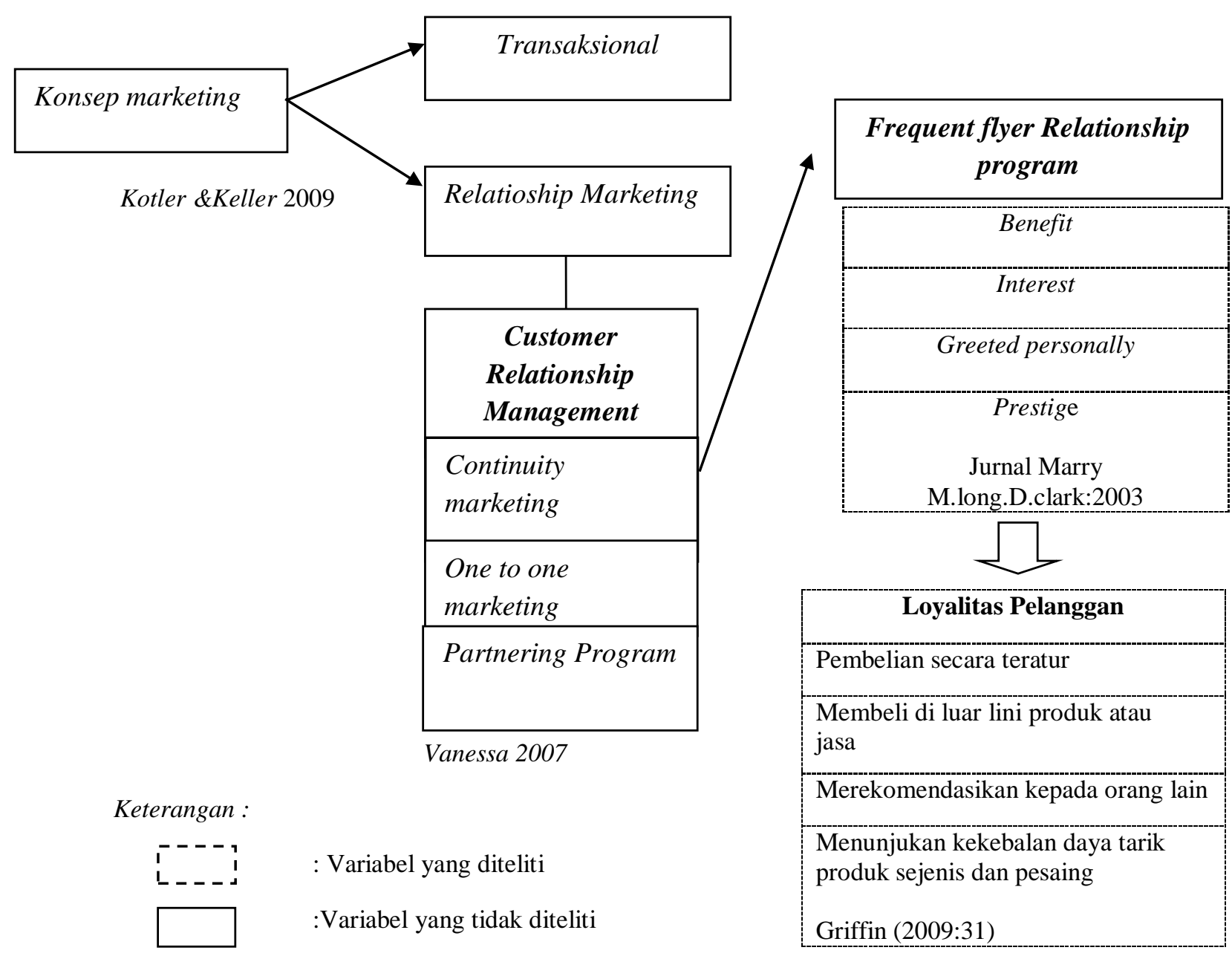

GAMBAR 2.3

KERANGKA PEMIKIRAN PENGARUH FREQUENT FLYER RELATIONSHIP PROGAM TERHADAP LOYALITAS PENUMPANG GARUDA INDONESIA 


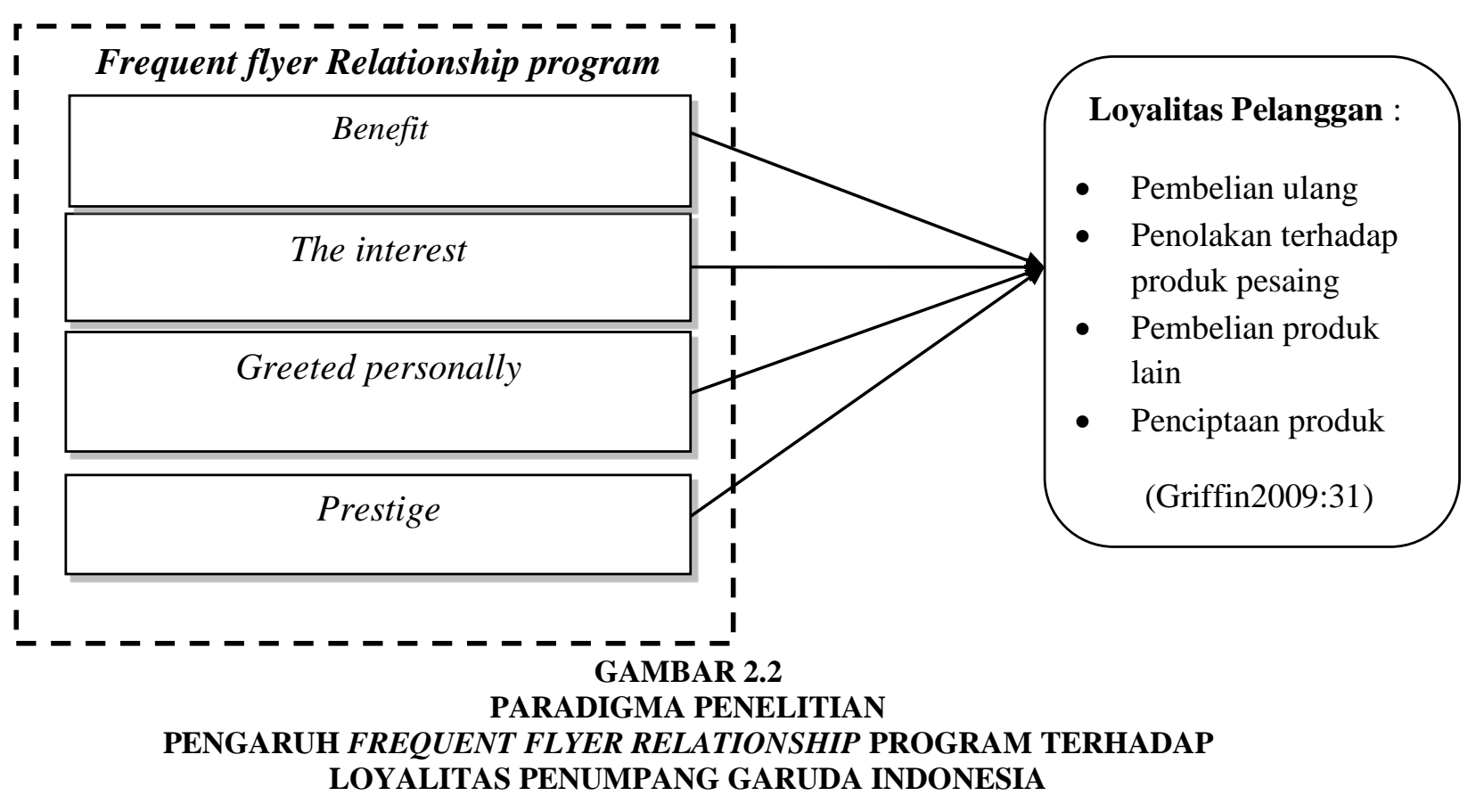

\subsection{Hipotesis}

Hipotesis merupakan jawaban Research Question yang diajukan. Hipotesis berasal dari kata hipo (=lemah) dan tesis (pernyataan). Pernyataan yang masih lemah perlu diuji apakah hipotesis dapat diterima atau tidak. Berdasarkan teori-teori yang telah dikemukakan maka diajukan hipotesis yang akan dibuktikan melalui penelitian. Hipotesis merupakan jawaban sementara terhadap masalah penelititan yang dibangun berdasarkan kerangka teoritis tertentu yang kebenarannya perlu diuji secara empiris. Hipotesis merupakan jawaban sementara terhadap rumusan masalah penelitian (Sugiono, 2009:221).

Penelitian dalam menyusun hipotesis didukung oleh beberapa premis sebagai berikut:

1. Progam relationship marketing adalah sebagai berikut:"implementing relationship marketing programmes that add to the consumers quality of life may be one way of achieving this strategy". menerapkan program-program relationship marketing yang menambah kualitas hidup konsumen mungkin salah satu cara untuk konsumen mungkin salah satu cara untuk mencapai strategi ini.

2. Mary M. Long, Sylvia D.Clark, Leon G. Schiffman and Charles Mchmellon dalam jurnal Frequent flyer Relationship program dikemukakan sebagai berikut:
Relationship marketing as it applies to service it also described as serving customer as client' in order to enhance the relationship from customer's point ot view. Thus, the goal of any relationship strategy is make customer loyal and maintain an on going relationship. Dapat diartikan sebagai berikut hubungan pemasaran yang berlaku untuk layanan itu juga digambarkan sebagai melayani pelanggan, strategi untuk meningkatkan hubungan dan membuat pelanggan loyal dan memelihara hubungan tersebut.

Dengan demikian, tujuan dari setiap strategi hubungan adalah membuat pelanggan setia dan memelihara hubungan yang sedang berjalan dari relationship strategy adalah untuk membuat para pelanggan loyal menjalin hubungan dalam jangka panjang. Type of relationship marketing programme, the frequency marketing program is widely used by many kinds of service providers including hotels,airlines,credit card and telephone companies. Frequent flyer programmes were introduced by American Airlines in 1981. Today, 70 airlines worldwide have a frequent flyer programme. Dapat diartikan salah satu program pemasaran frequent flyer secara luas dipakai oleh berbagai macam layanan pengguna hotel, Airlines, kartu kredit dan perusahan telepon. Frequent flyer program pertama dibuat oleh Amerika Airlines pada tgn 1981. Sekarang 
70 perusahaan penerbangan didunia mengunakan frequent flyer program atau membership program.

3. Menurut Sheth, parvatiyar dan Shaines dalam vanessa (2007:42) CRM mempunyai tiga tipe program yaitu continuity marketing, one to one marketing, dan partnering program. Ketiga program tersebut mempunyai bentuk yang berbeda yakni untuk pemakaian akhir, pelanggan distributor atau pelanggan. program continuity atau frequent flyer relationship program adalah untuk mempertahankan pelanggan dan meningkatkan loyalitas melalui pelayanan khusus jangka panjang

\section{METODE PENELITIAN}

\subsection{Objek Penelitian}

Penelitian ini menggunakan pendekatan ilmu manajemen pemasaran. Adapun objek penelitian terdiri dari dua variabel yaitu variabel $\mathrm{X}$ dan variabel $\mathrm{Y}$. Menurut Kerlinger yang dikutip oleh Sugiyono (2008:58), "Variabel adalah konstruk atau sifat yang akan dipelajari". Menurut Uma Sekaran (2006:115) "Variabel adalah apa pun yang dapat membedakan atau membawa variasi pada nilai".

Garuda Indonesia Airlines dipilih sebagai objek penelitian dengan pertimbangan bahwa objek ini perlu dilakukan penelitian mengenai, pengaruh frequent flyer relationship program penelitian ini dilakukan untuk mengetahui

\subsection{Jenis Penelitian Dan Metode yang Digunakan}

Metode penelitian adalah suatu ilmu tentang kerangka kerja melaksanakan penelitian yang bersistem yang berarti dikerjakan secara kontekstual. Konteks penelitian tersusun atas unsur-unsur yang terdiri dari filsafat yang menjadi pangkal beranjak pemikiran, berpikir yang membentuk gagasan dasar dan konsep, nalar yang menjalankan proses pemahaman persoalan yang menjadi buah telah dan selanjutnya menjalankan proses penarikan kesimpulan, takrif yang membuat batasan pemikiran tentang konsep sebagai abstraksi wujud dan asumsi yang menjadi latar belakang hipotesis dengan suatu implikasi tertentu.

Metode penelitian yang diigunakan dalam penelitian ini adalah metode penelitian deskriptif dan verifikatif. Menurut pendapat sugiono (2007:11) penelitian yang berpotensi untuk meningkatkan nilai melalui saling mempelajari

Berdasarkan pengertian hipotesis di atas dan premis tersebut, maka hipotesis dalam penelitian ini adalah: terdapat pengaruh signifikan antara frequent flyer relationship program yang terdiri dari benefit from these program (x1), the interest of this program daya tarik program frequent flyer (x2), greedet personally (pelayangan secara individu) (x3), prestige frequent flyer program (reward atau penghargaan dari program frequent flyer) (x4) terhadap loyalitas pelanggan pada Garuda Indonesia Airlines (didukung oleh premis 2 dan 3 ).

seberapa besar pengaruh frequent flyer relationship program yang dilakukan melalui program Garuda Frequent Flyer (GFF) yang terdiri dari benefit from these program $\left(\mathrm{x}_{1}\right)$, the interest of this program daya tarik program frequent flyer $\left(\mathrm{x}_{2}\right)$, greedet personally (pelayanan secara individu) $\left(\mathrm{x}_{3}\right)$, prestige frequent flyer program (reward atau penghargaan dari program frequent flyer) $\left(\mathrm{x}_{4}\right)$ terhadap loyalitas membership Garuda Indonesia. Penelitian ini juga dilakukan dalam kurun waktu selama enam bulan dengan menggunakan metode cross sectional.

deskriptif merupakan penelitian yang bertujuan memberikan gambaran dari variabel penelitian. Hal serupa dikemukakan oleh Travel Travens dalam Husein Umar (2006:21) bahwa "penelitian dengan menggunakan metode deskriptif adalah penelitian yang dilakukan untuk mengetahui nilai variabel mandiri, baik satu variabel atau lebih (independent) tanpa membuat perbandingan atau dengan menghubungkan variabel lain". Melalui jenis penelitian deskriptif maka dapat diperoleh deskripsi mengenai pengaruh frequent flyer relationship program dalam meningkatkan loyalitas member Garuda Indonesia.

Metode penelitian verifikatif adalah suatu metode yang menguji kebenaran suatu hipotesis yang dilakukan melalui pengumpulan data di lapangan, dalam hal ini penelitian verifikatif bertujuan untuk 
mengetahui pengaruh frequent flyer relationship program dalam meningkatkan loyalitas member Garuda Indonesia. Berdasarkan jenis penelitiannya yaitu deskriptif dan verifikatif maka metode yang digunakan dalam penelitian ini adalah survey explanotary.

Untuk memperoleh data tersebut, penulis perlu menterjemahkan variabel termasuk indikator ke dalam data operasional, sehingga dapat diketahui tentang jenis data yang diperlukan dengan data pengukurannya sebagai berikut:

1. Variabel Independen

Variabel ini merupakan variabel bebas yang mempengaruhi variabel lain dimana dalam penelitian ini yang menjadi variabel independen adalah frequent flyer relationship program yang dinotasikan sebagai variabel $\mathrm{X}$ yang terdiri dari benefit from these program (x1), the interest of this program daya tarik program frequent flyer (x2), greedet personally (pelayangan secara individu) (x3), prestige frequent flyer program (reward atau pengahargaan dari program frequent flyer) (x4).

2. Variabel Dependen

Variabel ini merupakan variabel terikat yang dipengaruhi oleh variabel lain dimana dalam penelitian ini yang menjadi variabel dependen adalah loyalitas pelanggan yang dinotasikan sebagai variabel Y. Variabel yang dijadikan objek pada penelitian kali ini dioperasikan variabelnya menggunakan skala ordinal yang akan ditransformasikan ke dalam skala interval dengan menggunakan MSI (Method of Successive Interval).

Berdasarkan ruang lingkup permasalahan yang telah dikemukakan di atas maka variabel- variabel yang akan diteliti dapat dijabarkan dalam tabel sebagai berikut:

TABEL 3.1

OPERASIONALISASI VARIABEL

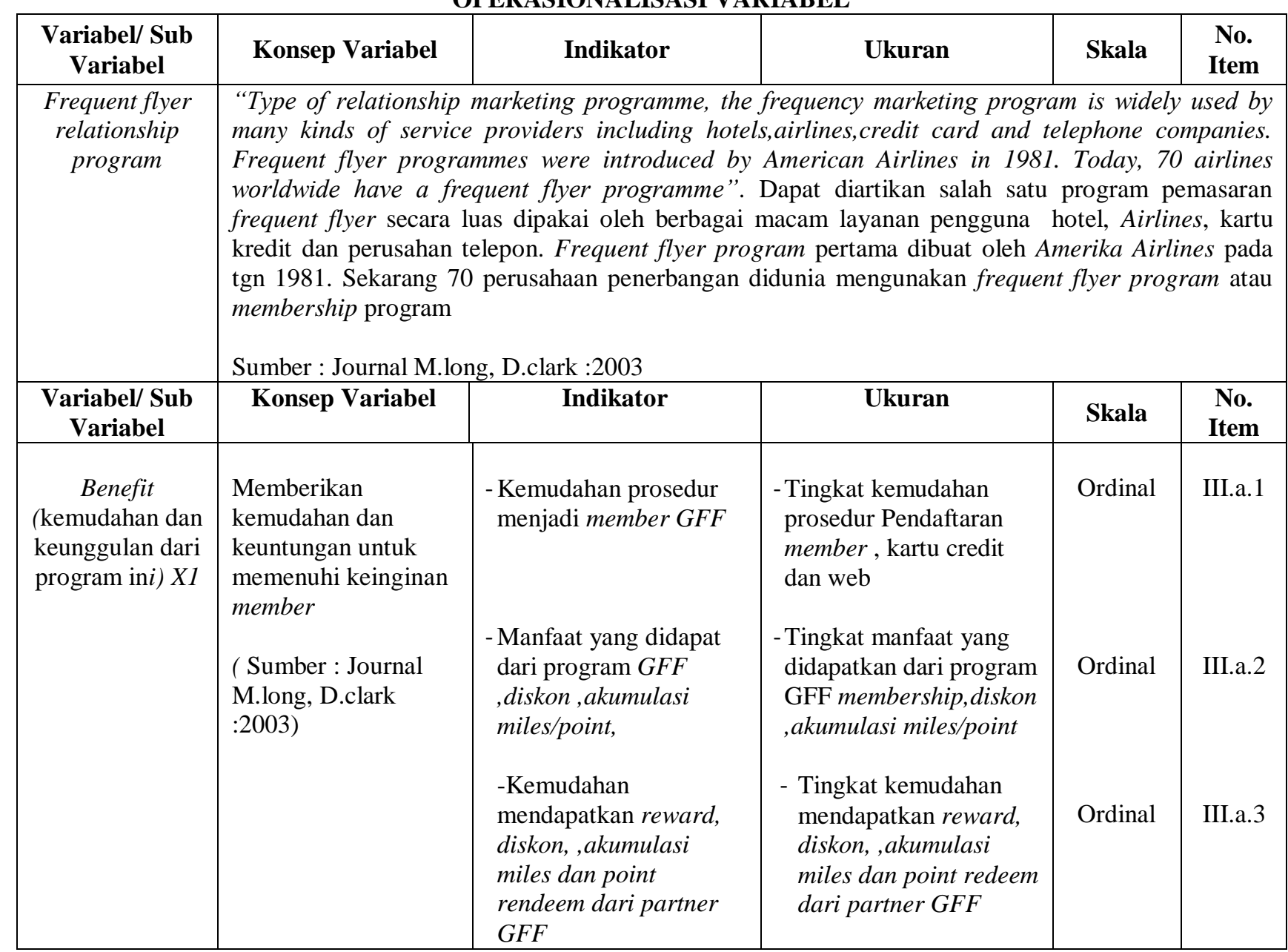




\begin{tabular}{|c|c|c|c|c|c|}
\hline interest $x 2$ & $\begin{array}{l}\text { Kemenarikan dari } \\
\text { program frequent } \\
\text { flyer relationship } \\
\\
\text { ( Sumber : Journal } \\
\text { M.long, D.clark } \\
: 2003 \text { ) }\end{array}$ & $\begin{array}{l}\text { - Daya tarik program } \\
\text { garuda frequent flyer } \\
\text {-Daya tarik dari diskon, } \\
\text { akumulasi miles, dan } \\
\text { reward }\end{array}$ & $\begin{array}{l}\text {-Tingkat daya tarik } \\
\text { program GFF } \\
\text {-Tingkat daya tarik dari } \\
\text { diskon, akumulasi } \\
\text { miles, dan reward }\end{array}$ & $\begin{array}{l}\text { Ordinal } \\
\text { Ordinal }\end{array}$ & $\begin{array}{l}\text { III.b.1 } \\
\text { III.b.2 }\end{array}$ \\
\hline $\begin{array}{l}\text { greedet } \\
\text { personally } \\
\text { (pelayangan } \\
\text { secara } \\
\text { individu)x3 }\end{array}$ & $\begin{array}{l}\text { Pelayanan frequent } \\
\text { flyer program yang di } \\
\text { terima pelanggan } \\
\text { ( Sumber : Journal } \\
\text { M.long, D.clark } \\
: 2003 \text { ) }\end{array}$ & $\begin{array}{l}\text { - Daya tarik } \\
\text { pelayanan } \\
\text { - Kemenarikan } \\
\text { kegiatan } \\
\text { pelayanan } \\
\text { lakukan } \\
\text { - Frekuensi } \\
\text { pelayanan yang } \\
\text { di terima }\end{array}$ & $\begin{array}{ll}- & \text { Tingkat daya } \\
\text { tarik pelayanan } \\
\text { - } & \text { Tingkat } \\
\text { keunikan } \\
\text { pelayanan } \\
\text { - Tingkat } \\
\text { frekuensi } \\
\text { pelayanan yang } \\
\text { berikan }\end{array}$ & $\begin{array}{l}\text { Ordinal } \\
\text { Ordinal } \\
\text { Ordinal }\end{array}$ & $\begin{array}{l}\text { III.c. } 1 \\
\text { III.c. } 2 \\
\text { III.c. } 3\end{array}$ \\
\hline Prestige X4 & $\begin{array}{l}\quad \begin{array}{l}\text { Life style } \\
\text { setelah } \\
\text { menjadi } \\
\text { member }\end{array} \\
\text { (Sumber : Journal } \\
\text { M.long, D.clark } \\
\text { :2003) }\end{array}$ & $\begin{array}{ll}\text { - } & \begin{array}{l}\text { Prestige yang } \\
\text { dirasakan } \\
\text { setelah } \\
\text { menggunakan } \\
\text { GFF }\end{array} \\
\text { - } \quad \begin{array}{l}\text { Kepuasan } \\
\text { menjadi } \\
\text { member GFF }\end{array} \\
\text { - Manfaat dari } \\
\text { leveing member } \\
\text { GFF }\end{array}$ & $\begin{array}{ll}\text { - } & \text { Tingkat prestige } \\
\text { yang dirasakan } \\
\text { setelah } \\
\text { menggunakan } \\
\text { GFF } \\
\text { - } \quad \text { Tingkat } \\
\text { kepuasan } \\
\text { menjadi } \\
\text { member GFF } \\
\text { Tingkat manfaat } \\
\text { dari level } \\
\text { member GFF }\end{array}$ & Ordinal & III.d.2 \\
\hline \multirow[t]{2}{*}{$\begin{array}{l}\text { Loyalias } \\
\text { pelanggan } \mathrm{Y}\end{array}$} & \multicolumn{5}{|c|}{$\begin{array}{l}\text { Suatu pola pembelian yang teratur dalam jangka waktu yang lama yang dilakukan oleh unit-unit } \\
\text { pembuat atau pengambilan keputusan. (Griffin, 2005:53) }\end{array}$} \\
\hline & & Pembelian secara teratur & $\begin{array}{l}\text { - Tingkat keinginan } \\
\text { member untuk } \\
\text { melakuka }\end{array}$ & Ordinal & Iv.a.1 \\
\hline
\end{tabular}




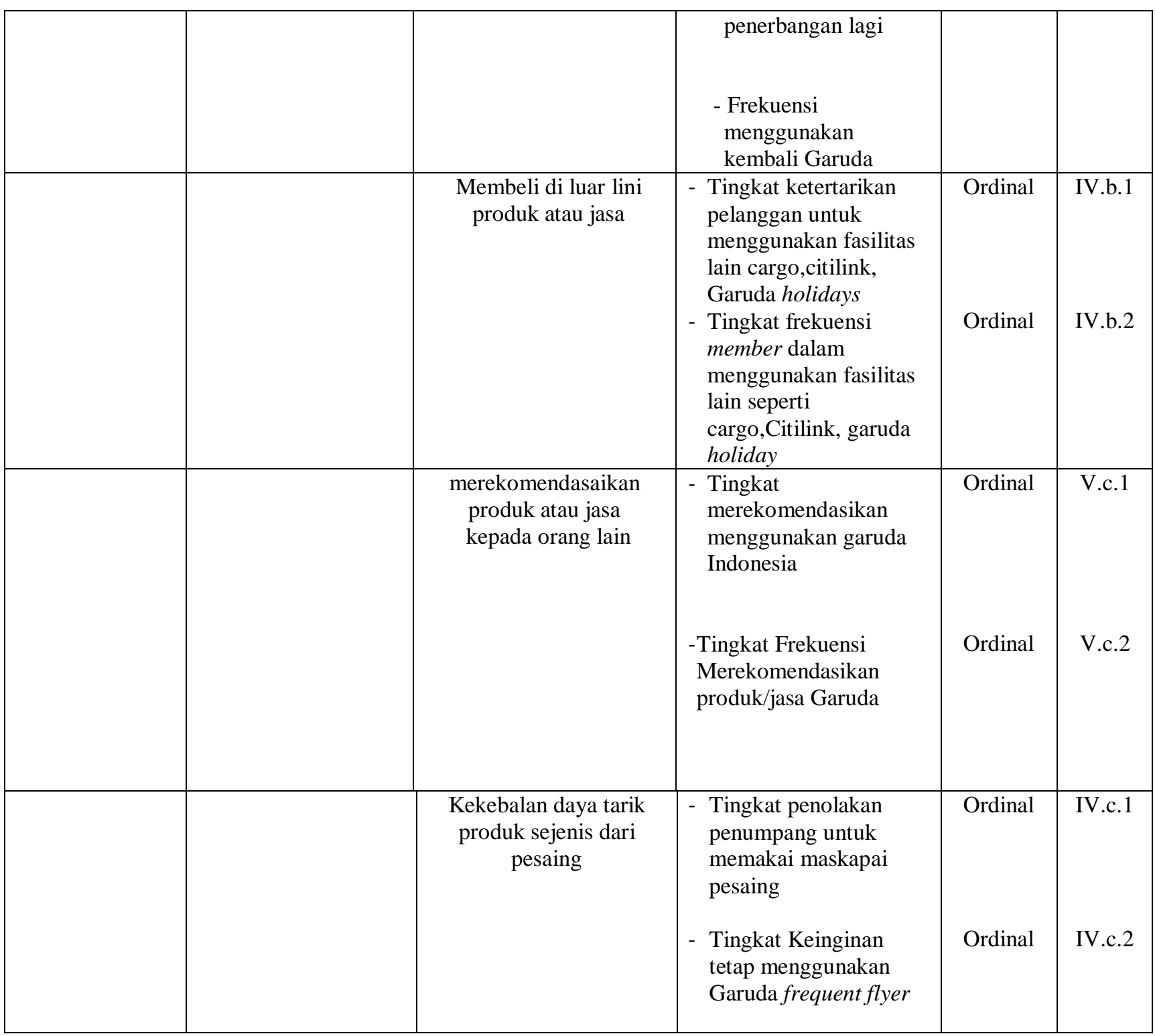

Sumber: diolah dari beberapa sumber literatur

\subsubsection{Populasi, Sampel dan Teknik Sampel \\ 3.2.4.1 Populasi}

Populasi merupakan sekelompok orang, kejadian, atau segala sesuatu yang memiliki karakteristik tertentu yang ingin mempelajari sifat-sifatnya. Di dalam pengumpulan dan menganalisa suatu data, langkah pertama yang sangat penting adalah menentukan populasi terlebih dahulu. Menurut Sugiyono, (2010:80) Populasi adalah wilayah generalisasi yang terdiri atas obyek atau subyek yang mempunyai kualitas dan karakteristik tertentu yang ditetapkan oleh peneliti untuk dipelajari dan kemudian ditarik kesimpulannya. Uma Sekaran
(2008:122) menyatakan Populasi merupakan kumpulan semua elemen dalam populasi di mana sampel diambil.

Berdasarkan definisi populasi di atas maka populasi pada penelitian ini adalah jumlah penumpang yang diperoleh dari pihak manajemen Garuda Indonesia berdasarkan jumlah member Garuda Frequent Flyer pada tahun 2012 yaitu sebanyak 578.354 member.

\subsubsection{Sampel}

Sugiyono (2009:116) mendefinisikan sampel adalah bagian dari jumlah ataupun karakteristik yang dimiliki oleh suatu populasi tertentu. Sampel juga merupakan 
sebagian dari jumlah dan karakteristik yang dimiliki oleh populasi tersebut. Apabila populasi besar dan peneliti tidak mungkin mempelajari semua yang ada populasi, hal ini dikarenakan adanya keterbatasan dana, tenaga dan waktu, maka peneliti dapat menggunakan sampel yang diambil dari populasi tersebut. Apa yang dipelajari dari sampel itu, kesimpulannya akan diberlakukan untuk populasi.

Berdasarkan pengertian mengenai sampel di atas, maka sampel yang diambil untuk penelitian ini adalah sejumlah orang yang dipilih dari populasi yaitu sebagian dari jumlah penumpang. Dalam penelitian ini peneliti melakukan

cara pegambilan sampel dengan menggunakan rumus sederhana dalam menentukan ukuran sampel yang dikembangkan oleh Slovin yang dapat dihutung dengan rumus sebagai berikut:

$$
n=\frac{N}{1+N d^{2}}
$$

Keterangan: $\mathrm{n}=$ ukuran sampel

$$
\mathrm{N}=\text { ukuran populasi }
$$$$
\mathrm{e}=\text { galat pendugaan }
$$

Berdasarkan perhitungan pada rumus Slovin, maka ukuran sampel pada penelitian ini adalah sebagai berikut:

$$
\begin{gathered}
n=\frac{578.354}{\left.1+(578.354) x(0.01)^{2}\right)} \\
=100 \\
\text { Berdasarkan teknik perhitungan }
\end{gathered}
$$
tersebut maka untuk penelitian ini dapat ditarik sampel sebanyak 100 orang.

\subsubsection{Teknik Sampel}

Teknik sampel merupakan suatu teknik pengambilan sampel yang akan digunakan dalam penelitian, untuk mendapatkan sampel representatif, maka harus diupayakan subjek dalam populasi memiliki peluang yang sama untuk menjadi sampel, sehingga peneliti menggunakan teknik probability sampling yang berarti teknik sampling memberi peluang yang sama bagi setiap unsur atau anggota populasi yang dipilih menjadi anggota sampel, khususnya Systematic Random Sampling.

Dimana teknik ini melakukan pengambilan sampel secara acak sistematis menurut interval tertentu yang dari setiap elemen dalam populasi akan memiliki peluang yang sama untuk dijadikan sempel
(Sugiono, 2010:81). Menurut Ulber Silalahi (2009:264) Systematic Random Sampling adalah teknik pemilihan sampel dari populasi yang dilakukan secara acak hanya untuk sampel yang pertama dari sejumlah sampel,sedangkan untuk sampel berikutnya dipilih secara sistematis. Maka dengan teknik tersebut peneliti melakukan survei yang dilakukan pada member Garuda frequent flyer

\subsubsection{Teknik Pengumpulan Data}

Penulis dalam penelitian ini melakukan penelitian dengan teknik pengumpulan data sebagai berikut:

1. Studi Kepustakaan (Library Research) Mengadakan penelitian dengan membaca literatur maupun sumber-sumber lainnya yang ada kaitannya dengan masalah yang diteliti

2. Studi Lapangan (Field Research)

Penelitian yang dilakukan pengamatan secara langsung terhadap objek yang diteliti dengan instrumen- instrumen sebagai berikut:

1. Observasi

Pengamatan secara langsung terhadap perilaku penumpang atau member

1. Wawancara

Proses memperoleh keterangan untuk tujuan memperoleh penelitian dengan melakukan tanya jawab dengan pegawai Garuda Indonesia Airlines

2. Kuesioner (Angket)

Sugiyono

(2008:142)

mengemukakan bahwa "kuesioner merupakan teknik pengumpulan data yang dilakukan dengan cara memberi seperangkat pertanyaan atau pernyataan tertulis kepada responden untuk dijawabnya". Kuesioner berisi pertanyaan dan pernyataan mengenai karakteristik responden. Teknik pengambilan data dengan menyebarkan pertanyaanpertanyaan yang tertulis untuk memperoleh data yang objektif. Kuesioner di tujukan kepada member garuda Indonesia Airlines

Teknik analisis data merupakan cara untuk mengukur, mengolah dan menganalisis data tersebut. Tujuan pengolahan data adalah untuk memberikan keterangan yang berguna serta untuk menguji hipotesis yang telah dirumuskan dalam penelitian ini. Dengan demikian, teknik analisis data diarahkan pada 
pengujian hipotesis serta menjawab masalah yang diajukan.

Proses untuk menguji hipotesis di mana metode analisis yang dilakukan dalam penelitian ini adalah metode analisis verifikatif, maka dilakukan analisis jalur (path analysis). Dalam hal ini, analisis jalur digunakan untuk menentukan besarnya pengaruh variabel independen $(\mathrm{X})$ terhadap variabel dependen (Y) baik secara langsung ataupun tidak langsung. Untuk memenuhi persyaratan digunakannya metode analisis jalur maka sekurang-kurangnya data yang diperoleh adalah data interval.

Data yang diperoleh dalam penelitian ini adalah data ordinal yang ditransformasikan menggunakan MSI. Adapun pengolahan data dapat dilakukan dengan menggunakan bantuan program SPSS for windows 18.0, Transformasikan data mentah menjadi data dalam skor $\mathrm{Z}$. Untuk itu pilih menu analyze, pilih descriptive statistic. Klik descriptive. Blok semua variabel, klik >. Klik Ok. Klik save untuk menyimpan data. Untuk memperoleh semua nilai PA, prosedurnya adalah dari menu utama analyze, pilih regression, klik linier. Pengisian kotak independen, blok semua variabel endogen, yaitu Zscore (Y) (yz) dan klik >. Pengisian kotak independen, blok semua variabel eksogen dan klik >. Method, pilih enter. Kemudian dari kotak statistik, klik descriptive. Untuk jelasnya proses analisis jalur dilakukan dengan langkah-langkah sebagai berikut.

Setelah data penelitian berskala interval selanjutnya akan ditentukan pasangan data variabel independen dari semua sampel penelitian. Berdasarkan hipotesis konseptual yang diajukan, terdapat hubungan antara tiap variabel penelitian. Hipotesis tersebut digambarkan dalam sebuah paradigma seperti terlihat pada Gambar 3.1 sebagai berikut:

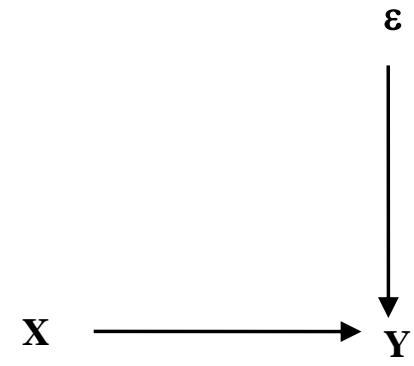

GAMBAR 3.1 STRUKTUR KAUSAL ANTARA X DAN Y
Keterangan: $\quad \mathbf{X}=$ Frequent flyer

Relationship program $\mathbf{Y}=$ loyalitas pelanggan
$\varepsilon=$ Epsilon (variabel lain)

Struktur hubungan di atas menunjukkan bahwa Frequent flyer Relationship program berpengaruh terhadap loyalitas penumpang. Selain itu terdapat faktor-faktor lain yang mempengaruhi hubungan antara Frequent flyer Relationship program yang terdiri dari benefit from these program $\left(\mathrm{x}_{1}\right)$, the interst of this program (daya tarik program frequent flyer) $\left(\mathrm{x}_{2}\right)$, greedet personally (pelayangan secara individu) ( $\left.\mathrm{x}_{3}\right)$, prestige frequent flyer program (reward atau pengahargaan dari program frequent flyer $\left(\mathrm{x}_{4}\right)$ dan $\mathrm{Y}$ (loyalitas penumpang) yaitu variabel residu dan dilambangkan dengan $\varepsilon$, namun pada penelitian ini variabel tersebut tidak diperhatikan.

Struktur hubungan antara Frequent flyer relationship program dan Loyalitas pelanggan diuji melalui analisis jalur dengan hipotesis yang berbunyi terdapat pengaruh yang signifikan antara Frequent flyer relationship program terhadap loyalitas pelanggan (Y). Pengujian hipotesis dilakukan dengan langkah-langkah sebagai berikut:

1. Menggambar struktur hipotesis

$\varepsilon$

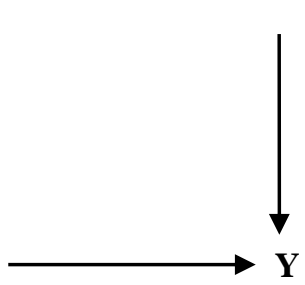

\section{GAMBAR 3.2 \\ DIAGRAM JALUR HIPOTESIS}

1. Selanjutnya diagram hipotesis di atas diterjemahkan ke dalam beberapa sub hipotesis yang menyatakan pengaruh sub variabel independen yang paling dominan terhadap variabel dependen. Lebih jelasnya dapat dilihat pada Gambar sebagai berikut.

2. Selanjutnya diagram hipotesis di atas diterjemahkan ke dalam beberapa sub hipotesis yang menyatakan pengaruh sub variabel independen yang paling dominan terhadap variabel dependen. Lebih jelasnya dapat dilihat pada Gambar 11 berikut.: 


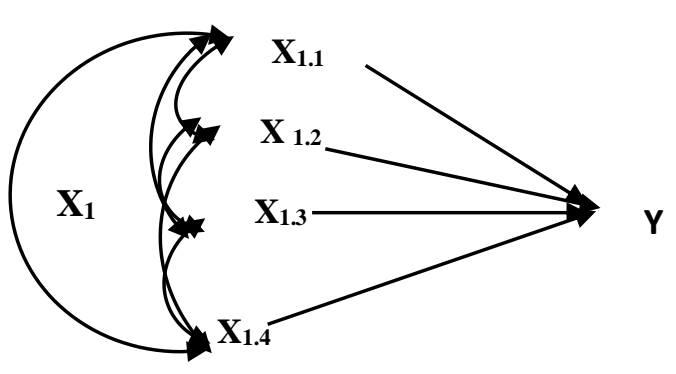

GAMBAR 3.3

JALUR SUB STRUKTUR HIPOTESIS

\section{Keterangan:}

$\mathbf{X}$ $\operatorname{program}(X)$

$\mathbf{X}_{\mathbf{1}}=$ benefit from these program (X1)

$\mathbf{X}_{\mathbf{2}}=$ the interest of this program (X2)

$\mathbf{X}_{\mathbf{3}} \quad=$ greedet personally $(\mathrm{X} 3)$

$\mathbf{X}_{4} \quad=$ prestige frequent flyer program (X4)

Y = Loyalitas pelanggan

$\boldsymbol{\varepsilon} \quad=$ Epsilon (Variabel Lain)

\section{Pengujian Hipotesis}

Data penelitian yang telah berskala interval selanjutnya akan ditentukan pasangan data variabel independen dengan variabel dependen serta akan ditentukan persamaan yang berlaku untuk pasanganpasangan tersebut.

Kriteria pengambilan keputusan hipotesis secara statistik dalam rangka pengambilan keputusan penerimaan atau penolakan hipotesis dapat ditulis sebagai berikut:
Hipotesis nol $H_{0}: \rho=0$ maka, tidak terdapat pengaruh signifikan antara frequent flyer relationship program yang terdiri dari benefit from these program (x1), the interest of this program daya tarik program frequent flyer (x2), greedet personally (pelayangan secara individu) (x3), prestige frequent flyer program (reward atau pengahargaan dari program frequent flyer) $(\mathrm{x} 4)$ terhadap peningkatan loyalitas member Garuda Indonesia

Hipotesis nol $H_{0}: \rho \neq 0$ maka, terdapat pengaruh signifikan antara frequent flyer relationship program terhadap loyalitas member Garuda Indonesia

\section{HASIL PENELITIAN DAN PEMBAHASAN}

Tujuan dari setiap strategi hubungan adalah membuat pelanggan setia dan memelihara hubungan yang sedang berjalan dari relationship strategy adalah untuk membuat para pelanggan loyal menjalin hubungan dalam jangka panjang. Berikut merupakan sub total skor dari masingmasing sub variabel sehingga dapat terlihat mana sub variabel yang memiliki tanggapan yang baik dari responden. Perhitungan skor variabel frequent flyer relationship program dapat dilihat pada Tabel 4.1 sebagai berikut:

TABEL 4.1

REKAPITULASI GAMBARAN FREQUENT FLYER RELATIONSHIP PROGRAM PADA

GARUDA INDONESI AIRLINES

\begin{tabular}{|c|c|c|c|c|c|}
\hline No & Sub Variabel & $\begin{array}{c}\text { Total } \\
\text { Skor }\end{array}$ & $\begin{array}{c}\text { Jumlah } \\
\text { Item } \\
\text { Pertanyaan }\end{array}$ & $\begin{array}{c}\text { Rata- Rata } \\
\text { Skor }\end{array}$ & $\mathbf{\%}$ \\
\hline 1 & Benefit & $\mathbf{1 1 5 9}$ & 3 & 308 & 25,54 \\
\hline 2 & Interest & 592 & 2 & 295 & 24,46 \\
\hline 3 & Greeted Personally & 967 & 4 & 302 & 25,05 \\
\hline 4 & Prestige & 951 & 3 & 301 & 24,96 \\
\hline \multicolumn{2}{r}{ Total } & $\mathbf{3 6 6 9}$ & $\mathbf{1 2}$ & $\mathbf{1 2 0 6}$ & $\mathbf{1 0 0}$ \\
\hline
\end{tabular}


Berdasarkan Tabel 4.10 menunjukan bahwa terdapat skor tertinggi sebersar 308 atau $25,54 \%$ yang memiliki tanggapan paling baik dari responden yaitu dari sub variabel benefit. Tanggapan yang baik diberikan oleh responden terhadap garuda Indonesia Airlines yang muncul dari persepsi mereka terhadap program GFF yaitu terdapt kemudahan dan keuntungan yang diberikan dari program GFF setelah menjadi member. Sedangkan sub variabel terendah dari interst yaitu sebesar 295 atau $24,46 \%$ dari sub variabel interest. Tanggapan yang diberikan kurang baik memiliki skor yang rendah dikarenakan oleh kurangnya memahaminya program GFF dan kurangnya informasi terdahap daya tarik dari program GFF oleh karena itu harus lebih ditingkatkan informasi yang berikan terhadap member maupun calon member.

Berdasarkan hasil pengolahan yang telah disajikan pada Tabel 4.9 persentase untuk variabel frequent flyer relationship program dihitung berdasarkan rumus Sugiyono (2010:94) yaitu:

- Nilai Indeks Maksimum

- $\quad=5 \times 12 \times 100=6000$

- Nilai Indeks Minimum

- $=1 \times 12 \times 100=1200$

- Jenjang variabel

- $=6000-1200=4800$

- Jarak Interval
- $\quad$ Jenjang : banyaknya kelas interval $=$ 4800: $5=960$

- Persentase skor $=[$ (total skor) : nilai maksimum] x $100 \%$ $=(3669: 6000) \times 1=61,15 \%$

Secara ideal skor yang diharapkan untuk jawaban dari member GFF terhadap pertanyaan 1 samapai dengan 12 adalah 6000. Dari perhitungan mendapatkan jumlah sebesar 3669 atau $61,15 \%$ dari skor ideal 6000. Hasil itu menunjukan bahwa frequent flyer relationship program Garuda Indonesia Airlines yang dinilai oleh member dapat dikatakan cukup tinggi. Pada saat posisi perusahaan berada pada posisi seperti ini, pihak manajemen GFF dapat mencari tahu letak dimana kekurangan dari program GFF ini yang diberikan berdasarkan penelitian ini. Dari tanggapan member GFF pihak manajemen Garuda Indonesia Airlines dapat meningkatkan program GFF, pelayanan yang baik dan SDM yang baik, agar kualitas dari program GFF ini semakin mendapatkan respon yang baik sehingga member dapat merasakan kemudahaan, keuntungan dan kepuasan dari program GFF. Jika persentase tersebut disajikan dalam garis kontinum maka dilihat seperti pada Gambar 4.2:

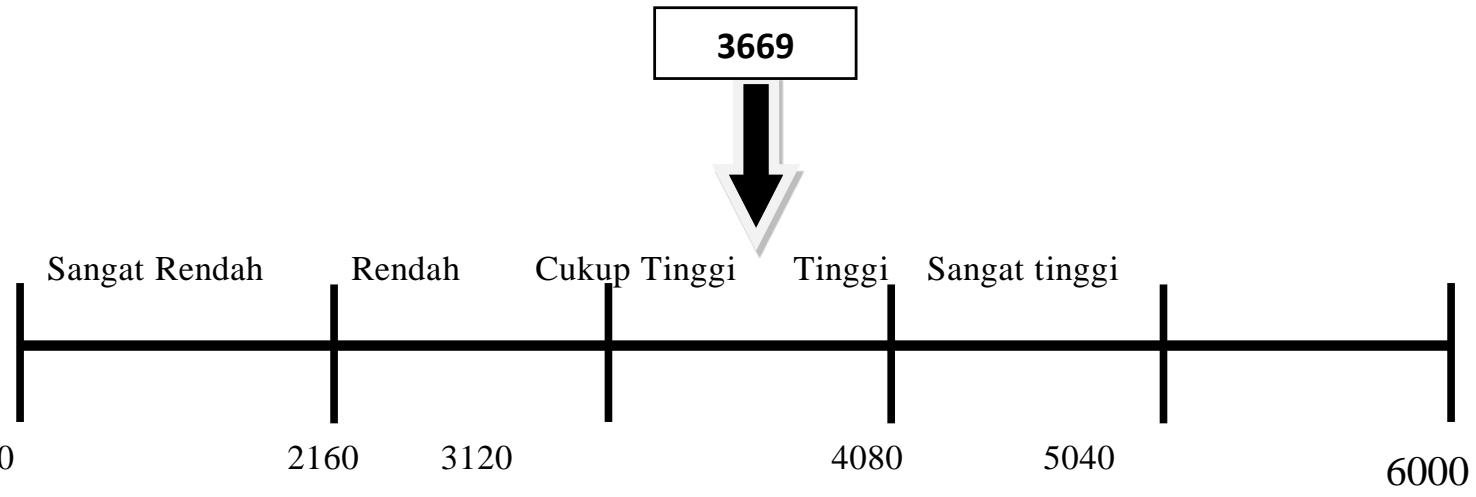

Sumber : Pengolahan Data 2012

GAMBAR 4.3

VARIABEL FREQUENT FLYER RELATIONSHIP PROGRAM PADA GARIS KONTINUM 
Berdasarkan Gambar 4.6 garis kontimum variabel frequent flyer Relationship proram berada pada garus cukup tinggi dengan nilai 3669 , skor tertinggi tedapat dari variabel benefit sebesar 308 atau 25,5 $\%$. Tanggapan member terhadap variabel benefit sangat baik, Menurut Mary $\mathrm{M}$. Long, Sylvia D.Clark, Leon G. Schiffman and Charles Mchmellon dalam jurnal frequent Flyer Relationship Program and Business Travellers' Quality of life (2007:422) Benefit from these program, memberikan konsumen dengan memberikan segala keuntungan dan kemudahan untuk memenuhi keinginan konsumen. Melalui kerjasama dengan beberapa tehnik dan program (membership\& potongan harga). hal ini karena member GFF merasakan banyak kemudahan dan keuntungan dari program GFF ini.

Berdasarkan hasil pengolahan yang telah disajikan diatas, dapat dilihat bahwa skor total untuk loyalitas Member Garuda Indonesia Airlines adalah 2480. Jumlah skor tersebut dimasukkan ke dalam garis kontinum, yang pengukurannya ditentukan dengan cara:

Nilai Indeks Maksimum $=$ Skala tertinggi $\mathrm{x}$ jumlah item pertanyaan $\mathrm{x}$ jumlah responden

$=5 \times 8 \times 100=4000$

Nilai Indeks Minimum

$=$ Skala terendah $\mathrm{x}$ jumlah item pertanyaan $\mathrm{x}$ jumlah

$$
=1 \times 8 \times 100=800
$$

Jenjang Variabel

$=4000-800=3200$

Jarak Interval

$=$ Jenjang : banyaknya kelas interval

$=3200: 5=640$

Persentase skor

$=[($ total skor $):$ nilai maksimum $] \times 100 \%$

$=(2480: 4000) \times 100 \%$

$=62 \%$

Jika skor tersebut disajikan dalam garis kontinum, maka dilihat seperti pada gambar berikut :

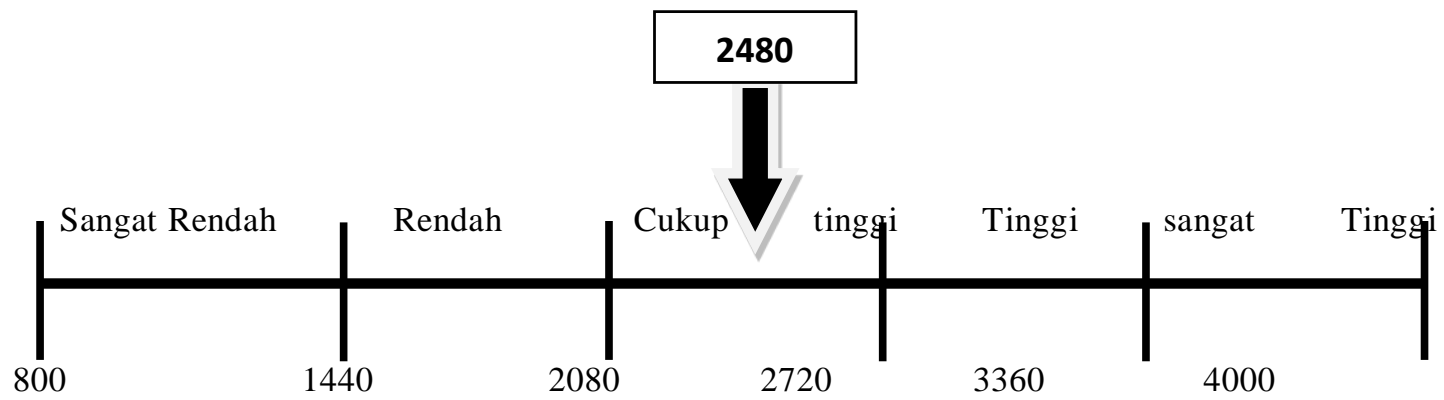

Sumber: Pengolahan Data 2012

\section{GAMBAR 4.6 VARIABEL LOYALITAS MEMBER PADA GARIS KONTINUM}

Berdasarkan garis kontinum di atas, dapat dikemukakan bahwa tanggapan terhadap loyalitas pelanggan secara keseluruhan berada pada kategori cukup tinggi 2480 dengan persentasi $62 \%$. Variabel yang memiliki rata- rata skor tertinggi yaitu item pembelian secara teratur, dengan demikian member Garuda Indonesia sudah melakuan pembelian secara teratur. Namun dari ke empat sub variabel loyalitas yang terdiri dari pembelian secara teratur, pembelian antar lini produk dan jasa, mereferensikan kepada orang lain, kekebalan terhadap tawaran pesaing, skor yang mempunyai niali rendah yaitu pembelian antar lini produk sebesar 21,15\%. hal ini karean member kurang berkeinginan untuk membeli antar lini produk dan jasa lain yang di tawarkan Garuda Indonesia, oleh karena itu pihak perusahan harus meningkatkan penawaran untuk memakai lini produk dan jasa sehingga member GFF tertarik. 


\subsection{Pengaruh Freqeunt Flyer Relationship Program terhadap loyalitas Member Garuda Indonesia Airlines}

Pengujian hipotesis dilakukan untuk menguji besarnya pengaruh frequent flyer relationship program (X) yang terdiri dari benefit $\left(\mathrm{X}_{1.1}\right)$, interest $\left(\mathrm{X}_{1.2}\right)$, greeted personally $\left(\mathrm{X}_{1.3}\right)$, prestige $\left(\mathrm{X}_{1.4}\right)$ terhadap Loyalitas pelanggan $\mathrm{Y}$, diperoleh hasil korelasi secara berurutan yaitu, benefit $\left(\mathrm{X}_{1.1}\right)$, interest $\left(\mathrm{X}_{1.2}\right)$, greeted personallu $\left(\mathrm{X}_{1.3}\right)$,prestige $\left(\mathrm{X}_{1.4}\right)$ terhadap loyalitas $(\mathrm{Y})$ baik secara simultan ataupun parsial, dilakukan dengan menggunakan uji statistik analisis jalur (path analysis). Selain itu, terdapat faktor-faktor lain yang mempengaruhi hubungan dari benefit $\left(\mathrm{X}_{1.1}\right)$, interest $\left(\mathrm{X}_{1.2}\right)$, greeted personally $\left(\mathrm{X}_{1.3}\right)$, prestige $\left(\mathrm{X}_{1.4}\right)$ terhadap Loyalitas pelanggan $\mathrm{Y}$ yaitu variabel residu yang dilambangkan dengan $\varepsilon$, namun pada penelitian ini variabel tersebut tidak diperhitungkan, serta untuk menguji hipotesis dihitung besarnya koefisien jalur masing-masing variabel

Selanjutnya berdasarkan perhitungan statistik yang didasarkan pada angka-angka dari masing-masing variabel terlebih dahulu dilakukan transformasi, dimana dalam perhitungan transformasi dilakukan dengan program yang ada dalam SPSS Versi 18.0. secara lengkap hasil pengolahan data pengaruh pelakasanaan frequent flyer relationship program beserta empat sub variabelnya terhadap loyalitas penumpang garuda indonesia airlines. Transformasi data variabel menjadi $\mathrm{Z}$ score, lalu menghitung koefisien korelasi antar variabel penelitian disajikan secara rinci.

Pada Tabel 4.17 memperlihatkan secara lengkap berdasarkan perhitungan statistik hasil pengolahan data pengaruh freqeunt flyer relationship beserta empat sub variabelnya terhadap loyalitas pelanggan di Garuda Indonesia Airlines sebagai berikut:

\begin{tabular}{|l|c|c|c|c|c|}
\hline & $\begin{array}{c}\text { loyalitas } \\
(\mathbf{Y})\end{array}$ & $\begin{array}{c}\text { benefit } \\
\text { (X1.1) }\end{array}$ & $\begin{array}{c}\text { interest } \\
\text { (X1.2) }\end{array}$ & $\begin{array}{l}\text { greeted } \\
\text { personally } \\
\text { (X1.3) }\end{array}$ & $\begin{array}{l}\text { prestige } \\
\text { (X1.4) }\end{array}$ \\
\hline $\begin{array}{l}\text { loyalitas } \\
\text { (Y) }\end{array}$ & 1000 & 0,876 & $\mathbf{0 , 7 2 1}$ & $\mathbf{0 , 4 7 9}$ & 0,876 \\
\hline $\begin{array}{l}\text { benefit } \\
\text { (X1.1) }\end{array}$ & 0,876 & 1.000 & $\mathbf{0 , 9 3 5}$ & $\mathbf{0 , 7 7 6}$ & 0,799 \\
\hline $\begin{array}{l}\text { interest } \\
\text { (X1.2) }\end{array}$ & $\mathbf{0 , 7 2 1}$ & $\mathbf{0 , 9 3 5}$ & 1.000 & 0,725 & 0,965 \\
\hline $\begin{array}{l}\text { greeted } \\
\text { personally } \\
\text { (X1.3) }\end{array}$ & $\mathbf{0 , 5 7 9}$ & $\mathbf{0 , 7 7 6}$ & 0,725 & 1.000 & 0,807 \\
\hline $\begin{array}{l}\text { prestige } \\
\text { (X1.4) }\end{array}$ & $\mathbf{0 , 6 1 3}$ & 0,799 & 0,965 & 0,807 & 1.000 \\
\hline
\end{tabular}

Sumber: Pengolahan Data, 2012

TABEL 4.2

MATRIKS KORELASI ANTAR SUB VARIABEL FREQUENT FLYER RELATIONSHIP PROGRAM TERHADAP LOYALITAS MEMBER

\section{Uji Parsial}

Hasil pengujian secara keseluruhan memberikan hasil yang signifikan, maka untuk mengetahui variabel bebas mana yang secara parsial berpengaruh nyata terhadap $\mathrm{Y}$ dapat dilanjutkan dengan pengujian secara parsial. Pengujian koefisien jalur dapat dilihat sebagai berikut: 
TABEL 4.19

PENGUJIAN PARSIAL

\begin{tabular}{|c|c|c|c|c|c|c|}
\hline No & \multicolumn{2}{|c|}{ Koefisien Jalur } & thitung & $\begin{array}{c}\mathbf{t} \\
\text { tabel }\end{array}$ & Keputusan & Kesimpulan \\
\hline 1 & $\mathrm{P}_{\mathrm{y} \times 1.1}$ & 0,195 & 1.985 & 1,660 & $\mathrm{H}_{0}$ ditolak & Signifikan \\
\hline 2 & $\mathrm{P}_{\mathrm{y} \times 1.2}$ & 0,202 & 2.061 & 1,660 & $\mathrm{H}_{0}$ ditolak & Signifikan \\
\hline 3 & $\mathrm{P}_{\mathrm{y} \times 1.3}$ & 0,204 & 2.088 & 1,660 & $\mathrm{H}_{0}$ ditolak & Signifikan \\
\hline 4. & $\mathrm{P}_{\mathrm{yx} 1.4}$ & 0,200 & 2.041 & 1,660 & $\mathrm{H}_{0}$ ditolak & Signifikan \\
\hline
\end{tabular}

Sumber : Pengolahan Data 2011

Secara lengkap struktural kausal antara sub variabel yang terdiri dari benefit $\left(\mathrm{X}_{1.1}\right)$, interest $\left(\mathrm{X}_{1.2}\right)$, greeted personally
$\left(\mathrm{X}_{1.3}\right)$, prestige $\left(\mathrm{X}_{1.4}\right)$ terhadap Loyalitas pelanggan $\mathrm{Y}$,dapat dilihat pada Gambar 4.24 berikut:

$\mathrm{X}_{1.1}$

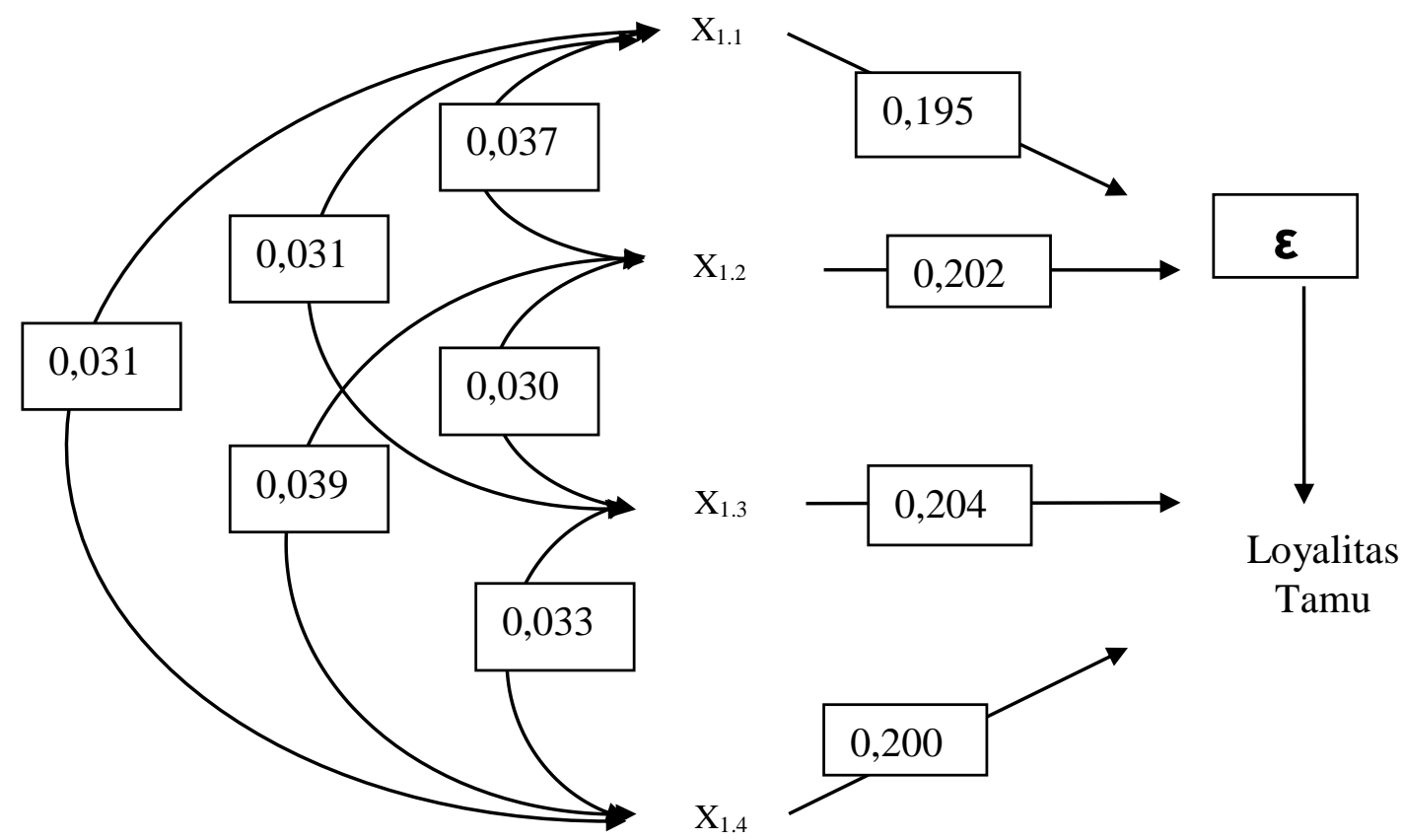

\section{GAMBAR 4.8 \\ DIAGRAM JALUR PENGUJIAN HIPOTESIS}

Menggambarkan struktur hubungan kausal $\mathrm{X}_{1}, \mathrm{X}_{2}, \mathrm{X}_{3}, \mathrm{X}_{4}$ terhadap $\mathrm{Y}$, dimana pengujian hipotesis dalam penelitian ini menggunakan analisis jalur. Analisis jalur digunakan untuk mengetahui pengaruh langsung dan tidak langsung antara benefit,

\subsection{Temuan Penelitian Bersifat Empirik}

Berdasarkan yang dilakukan di Garuda Indonesia Airlines menghasilkan tanggapan mengenai pelaksanaan frequent flyer Relationship program garuda indonesia yang meliputi benefit, interest, greeted personally dan prestige. Berdasarkan fakta tersebut benefit memperoleh nilai tertinggi interest, greeted personally dan prestige terhadap loyalitas . untuk meningkatkan program GFF dan meningkatkan loyalitas member.

dikarenakan persepsi yang diberikan member sangat baik karena program garuda frequent flyer memberikan keuntungan dan kemudahan kepada member, oleh karena itu tanggapan member atas benefit yang dirasakan mendapatkan nilai tertinggi.

1. Kontribusi paling tinggi anatar variabel loyalitas yaitu melakukan 
pembelian secara teratur hal tersebut menunjukkan bahwa mayoritas member garuda slalu melakuan penerbangan berulang karena merasa puas oleh pelayanan garuda indonesia Airlines yang mengakibatkan selalu melakukan pembelian ulang.

2. Penelitian ini memperkuat bahwa frequent flyer relationship program berpengaruh terhadap loyalitas, dan salah satu strategy untuk memelihara dan meningkatkan loyalitas member Garuda Indonesia yang meliputi benefit, interest, greteed personally dan prestige merupakan faktor yang efektif bagi Garuda Indonesia Airlines sebagai alternatif strategi guna meningkatkan dan mempertahankan loyalitas member Garuda Indonesia Berdasarkan hasil temuan tersebut. maka diyakini hasil penelitian penulis mampu memberikan sumbangsih ilmiah bagi pengembangan ilmu manajemen pemasaran pariwisata mengenai frequent flyer Relationship program, khususnya manajemen Airlines dan juga sebagai masukan yang inspiratif dan konstruktif bagi Gadruda Indonesia Airlines.

\section{KESIMPULAN}

Berdasarkan hasil penelitian yang telah dilakukan dengan menggunakan analisis deskriptif dan verifikatif dengan mengunakan analisis path, antara frequent flyer relationship program terhadap loyalitas penumpang garuda indonesia airlines, maka berdasarkan penelitian tersebut diambil kesimpulan sebagai berikut:

1. Secara keseluruhan tanggapan member Garuda Freqeunt flyer terhadap tanggapan frequent flyer realtionship program di garuda indonesia airlines yang terdiri dari benefit, interest, greeted personally, dan prestige mendapatkan respon yang baik. Pelaksanaan sub variabel frequent flyer realtionship program sudah dilaksanakan cukup baik, terbukti dari tanggapan pelanggan terhadap frequent flyer realtionship program yang berada pada posisi yang cukup tinggi pada garis kontinum.
Pelaksanaan pada sub variabel benefit mendapat skor tertinggi sebersar 308 atau $25,54 \%$ yang memiliki tanggapan paling baik dari responden yaitu dari sub variabel benefit. Tanggapan yang baik diberikan oleh responden terhadap garuda Indonesia Airlines yang muncul dari persepsi mereka terhadap program GFF yaitu terdapat kemudahan dan keuntungan yang diberikan dari program GFF setelah menjadi member. Sub variabel interst yaitu sebesar 295 atau $24,46 \%$ dari sub variabel interest. Tanggapan yang diberikan kurang baik memiliki skor yang rendah dikarenakan oleh kurangnya memahaminya program GFF dan kurangnya informasi terdahap daya tarik dari program GFF oleh karena itu harus lebih ditingkatkan informasi yang berikan terhadap member.

2. Tanggpan penumpang terhadap loyalitas yang terdiri dari pembelian ulang secara teratur, pembelian di luar lini produk dan jasa, referensi kepada orang lain serta kekebalan terhadap tawaran pesaing secara umum mendapatkan tanggapan yang baik dari pelanggan. loyalitas penumpang Garuda Indonesia Airlines dalam melakukan pembelian ulang secara teratur mendapatkan skor tinggi yaitu sebesar 348 atau 26,10\%. Para penumpang Mereferensikan kepada teman, saudara atau kolega untuk menggunakan produk atau jasa garuda indonesia Airlines. Sedangkan skor yang rendah terdapat pada sub variabel pembelian antar lini produk dan jasa dengan skor yaitu 279 atau $21,15 \%$. Garuda indonesia airlines mempunyai lini produk dan jasa selain penerbangan akan tetapi kurang banyak digunakan akan tetapi tidak menggurangi kesetian penumpang. Pada tahapan loyalitas, loyalitas member GFF berada pada posisi client dimana pemumpang sudah melakukan pembelian ulang secara teratur.

3. Dalam penelitian ini diperoleh hasil bahwa frequent flyer Relationship program yang terdiri dari benefit, interest, greeted personally dan prestige secara signifikan mempengaruhi loyalitas. Namun variabel greeted personally dan prestige mempunyai pengaruh yang kecil terhadap loyalitas. Pengaruh yang paling besar diperoleh dari variabel benefit yaitu sebesar $3,9 \%$. 


\section{DAFTAR PUSTAKA}

Kotler, Philip \& Kevin Lane Keller. 2009.

Manajemen Pemasaran. Jakarta:

PT. Indeks Kelompok Gramedia

Tjiptono, Fandy. 2007. Pemasaran Jasa.

Malang: Bayumedia Publishing

Hasan, Ali. 2008. Marketing. Yogyakarta: Medpress

Gaffar, Vanessa. 2007. CRM dan MPR

Hotel. Bandung: Alfabeta.

Griffin, Jill. 2005. Customer Loyalty, alih

Bahasa Indonesia. Jakarta:

Erlangga.

M.long, D.clark :2003. Journal Frequent

flyer Relationship Program and

Business Travellers Quality of Life :

New York.

Assion Lawson-Body, Moez Limayem. 2007.

Journal the Impact of Customer

Relationship Management on

Customer Loyalty: The Moderating

Role of website

Ratih Hurriyati. 2010. Bauran Pemasaran dan Loyalitas Konsumen. Bandung: Alfabeta.

Lovelock, Christoper, and Wirtz. 2011. Services Marketing, $7^{\text {th }}$ edition. Pearson.

Santoso, Drs. Gempur M.Kes. 2005.

Metodologi Penelitian Kuantitatif \&

Kuanlitatif, Prestasi Pustaka

Publisher: Jakarta

Schiffman, Leon.G. dan Kanuk, Leslie, 2008. 5.

Consumer Behavior. Prentice

Hall InternasionalInc.

Sugiyono.2009. Metode Penelitian

Bisnis, Alfabeta:Bandung
Oka A. Yoeti. 2007. Pengantar Ilmu

Pariwisata. Bandung: Angkasa

Ismaun. 2006. Diktat Mata Kuliah Pengantar Ilmu Pariwisata. Bandung: Universitas Pendidikan Indonesia

Suharto Abdul Majid, Eko Prabo D. Warpani. 2009. Ground Handling Manajemen Pelayanan darat Perusahaan Penerbangan. Rajawali Pers. Jakarta

Undang-Undang Republik Indonesia Nomor

10 Tahun 2009 Tentang

Kepariwisataan, Jakarta, Indonesia.

\section{Situs Internet}

www.bandungtourism.com

www.bps.go.id

www.google.com

www.wikipedia.com

www.gff.garuda-indonesia.com

http://www.dephub.go.id/

http://hubud.dephub.go.id/?id+page+detail $+30$ 